\title{
SOSIALISASI PEMBUATAN POKAK JAHE UNTUK MENINGKATKAN IMUNITAS DIMASA PANDEMI COVID-19 DI SUMBERKEDAWUNG LECES PROBOLINGGO
}

\author{
Mutinda Teguh Widayanto, Ainul Yaqin, Erika Hamim, Bulan Sari, \\ Zainaf \\ Universitas Panca Marga \\ e-mail: mutindateguh@upm.ac.id
}

\begin{abstract}
The Covid-19 pandemic that has hit almost all regions of the world has affected various sectors of people's lives. Restrictions on community activities due to avoiding the spread of the virus prevent activities from being carried out properly. The educational, social and economic sectors coud not be avoided by this pandemic. Efforts to deal with virus transmission were also made. Various studies have been conducted to overcome these problems. One of the factors that can overcome the impact of a virus attack is the presence of good body immunity. The traditional Pokak Jahe drink is known to contain herbal ingredients that have properties that can increase the body's immunity from virus attacks. This community service activity in the form of socializing the making of Pokak Jahe aims to provide an understanding of the benefits and to socialize how to make Pokak Jahe drink as a traditional drink that is useful for increasing body immunity during the Covid-19 pandemic. It is hoped that the community will understand these benefits and be able to make Pokak Jake drinks for consumption and commercialization so that they can increase their immunity.
\end{abstract}

Keywords: Pokak Jahe, Immunity, Covid- 


\section{ABSTRAK}

Pandemi Covid-19 yang melanda hampir seluruh wilayah di dunia telah mempengaruhi berbagai sektor kehidupan masyarakat. Pembatasan kegiatan masyarakat karena menghindari penyebaran virus menyebabkan aqktivitas tidak bisa dilaksanakan sebagaimana mestinya. Bidang pendidikan, sosial dan ekonomi tak luput dari pengaruh tersebut. Upaya untuk mengatasi penularan virus juga dilakukan. Berbagai penelitian dilakukan untuk mengatasi permasalahan tersebut. Salah satu faktor yang dapat mengatasi dampak dari serangan virus adalah adanya imunitas tubuh yang baik. Minuman tradisional Pokak Jahe diketahui mengandung bahan herbal yang mempunyai khasiat dapat meningkatkan imunitas tubuh dari serangan virus. Kegiatan pengabdian masyarakat berupa sosialisasi pembuatan Pokak Jahe ini bertujuan untuk memberi pemahaman manfaat dan mensosialisasican cara pembuatan minuman Pokak Jahe sebagai minuman tradisional yang bermanfaat untuk meningkatkan imunitas tubuh di masa pandemi Covid-19 ini. Diharapkan masyarakan memahami manfaat tersebut dan mampu membuat minuman Pokak Jake untuk dikonsumsi dan untuk dikomersiilkan sehingga dapat meningkatkan imunitas mereka.

Kata Kunci: Pokak Jahe, Imunitas, Covid-19 


\section{A. PENDAHULUAN}

Virus corona (covid-19) yang ditemukan pada awal Desember 2019 di Wuhan, Cina hingga saat ini telah menyebah ke seluruh penjuru dunia. Dampak yang ditimbulkan oleh virus ini cukup bervariasi mulai yang ringan seperti terkena flu biasa hingga yang berakibat fatal hingga menyebabkan kematian. Hal yang membuat panik masyarakat adalah penebarannya yang relatif cepat, sehingga WHO menyatakannya sebagai pandemi.

Untuk menghindari wabah tersebut berbagai upaya dilakukan misalnya menggunakan masker, mendcuci tangan, menggunakan hand sanitizer dan menjaga jarak. Untuk efektifitas usaha tersebut Pemerintah mengambil kebijakan Pembatasan Sosial Berskala Besar (PSPB) yang membatasi berbagai aktivitas masyarakat terutama yang mendorong berlumpulnya massa. Berbagai dampak muncul dari pembatasan tersebut, baik di bidang Pendidikan, Sosial dan Ekonomi. Berbagai penelitian dilakukan untuk menemukan solusi agar orang yang terpapar virus dapat sembuh dan agar orang tidak mudah terpapar virus tersebut. Berbagai referensi menyebutkan bahwa daya tahan tubuh (imunitas) yang baik dapat mengurangi risiko terpapar virus ini.

Sumberkedawung adalah sebuah desa yang berada di Kecamatan Leces, Kabupaten Probolinggo. Sebagai sebuah desa dengan kepadatan penduduk yang tergolong tinggi, risiko terpapar virus di masa pandemi in juga dialami oleh desa ini. Berbagai upaya untuk meminimalisir meluasnya wabah di desa ini juga sudah dilakukan sesuai arahan dari Dinas Kesehatan Pemerintah Daerah.

Disamping usaha dari pihak pemerintah, peran serta masyarakat juga dibutuhkan dalam upaya ini. Perguruan Tinggi dengan Misi Tridharma yang ada dapat juga dapat memberikan peran sertanya dalam upaya pananggulangan wabah ini. Universitas Panca Marga sebagai institusi 
perguruan tinggi yang berada di wilayah Kabupaten Probolinggo juga ikut berupaya memberikan kontribusi dalam upaya menjaga masyarakat agar tidak tertular virus.

Disamping selalu menerapkan protokol kesehatan, salah satu usaha agar terhindar dari wabah ini adalah meningkatkan daya tahan atau imunitas agar mampu melawan serangan virus. Salah satu cara meningkatkan imunitas tubuh adalah dengan mengkonsumsi minuman Pokak Jahe yang merupakan minuman tradisional berasal dari Probolinggo (Fitria, 2020) dan mengandung bahan-bahan yang dapat meningkatkan imunitas. Atas dasar pertimbangan tersebut maka Kelompok KKN Universitas Panca Marga mengadakan kegiatan untuk mensosialisasikan pembuatan minuman Pokak Jahe sebagai upaya meningkatkan imunitas di masa pandemi Covid-19. Kegiatan ini adalah sebagai salah satu wujud Tridharma Perguruan Tinggi yaitu sebagai bentuk kegiatan pengabdian kepada masyarakat yang ada di wilayah sekitar (Widayanto, 2019).

\section{Analisis Situasi}

Desa Sumberkedawung berlokasi di arah selatan Kecamatan Leces, Kabupaten Probolinggo. Luas wilayah desa Sumberkedawung 382 Ha., (BPS, 2020) yang terbagi ke dalah 5 dusun, $10 \mathrm{RW}$ dan $76 \mathrm{RT}$, desa ini tergolong sebagai desa Swasembada. Batas-batas Desa Tigasan Wetan dapat diuraikan sebagai berikut :

a. Sebelah Utara : Desa Clarak;

b. Sebelah Timur : Desa Banjarsawah

c. Sebelah Selatan : Desa Tigasan wetan;

d. Sebelah Barat : Desa Leces

Jumlah peduduk Desa Sumberkedawung, sesuai data dari Biro Pusat Statistik (BPS,2020) berjumlah 11.397 jiwa yang terdiri dari 3.655 Kepala Keluarga, dan merupakan desa dengan jumlah penduduk terbanyak di Kecamatan 
Leces. Mata pencaharian penduduk desa ini cukup beragam, yaitu sebagai Petani, PNS, Swasta, Pedagang dan Wirausaha. Berbagai lembaga pendidikan mulai dari tingkat PAUD hingga tingkat Akademi ada di desa ini. Sesuai dengan lahan yang tersedia, produksi pertanian terbesar di desa ini adalah Bawang Merah dan Padi. Tingkat pendidikan warga sebagaian besar tamat SLTP/SLTA sebesar 70\%.

\section{Permasalahan}

Meluasnya pandemi covid-19 menyebabkan berbagai permasalahan di bidang, ekonomi, pendidikan dan sosial pada gilirannya juga menyentuh kehidupan masyarakat di pedesaan, untuk itu upaya-upaya untuk menanggulangi wabah ini harus dilakukan tidak hanya oleh pemerintah, tetapi juga oleh masyarakat. Peningkatan imunitas adalah salah satu hal yang dapat mengatasi agar tidak terpapar oleh virus Covid-19. Pokak Jahe adalah minuman tradisional dari Probolinggo yang bahan-bahan pembuatannya mudah didapatkan dan pembuatannya cukup mudah serta bisa meningkatkan imunitas di masa pandemi ini. Untuk itu Minuman Pokak Jahe ini perlu disosialisasikan manfaat dan cara pembuatannya agar masyarakat bisa mengkonsumsi sehingga imunitasnya meningkat. Untuk mewujudkan usaha tersebut terdapat beberapa permasalahan diantaranya :

a. Belum paham tentang manfaat Minuman Pokak Jahe dalam kaitannya dengan peningkatan imunitas dimasa pandemi

b. Belum mengetahui cara pembuatan Minuman Pokak Jahe

Atas dasar permasalahan tersebut maka dilakukan kegiatan pengabdian masyarakat bersama-sama dengan ibu-ibu anggota PKK Desa Sumberkedawung : "Sosialisasi Pembuatan Pokak Jahe Untuk Meningkatkan Imunitas Pada Masa Pandemi Covid-19 di Desa Sumberkedawung, Kecamatan Leces, Kabupaten Probolinggo”. Sedangkan tujuan dari kegiatan ini adalah : 
a. Mensosialisasikan manfaat minuman Pokak Jahe dalam meningkatkan imunitas di masa pandemi Covid-19

b. Mensosialisasikan cara pembuatan minuman Pokak Jahe di kalangan ibuibu anggota PKK desa

c. Tumbuhnya ide untuk memproduksi Minuman Pokak Jahe untuk tujuan komersial

d. Membagikan hasil pembuatan minuman Pokak Jahe kepada warga dan aparat desa Sumberkedawung.

\section{Pandemi Covid-19}

Covid-19 (coronavirus disease 2019) ialah penyakit yang penyebabknya adalah jenis coronavirus baru yaitu Sars-CoV-2, yang dilaporkan untuk pertama kali di kota Wuhan Tiongkok tanggal 31 Desember tahun 2019. Covid-19 ini bisa menyebabkan gejala gangguan pada pernafasan akut misalnya demam hingga diatas $38^{\circ} \mathrm{C}$, sesak nafas dan batuk bagi manusia (Aswani, 2020). Disamping itu dapat pula disertai dengan lemas, otot nyeri, serta diare. Bagi penderita Covid-19 berat, bisa menimbulkan pneumonia, sindroma pernafasan akut, gagal ginjal bahkan hingga kematian. Virus ini menyebar sangat cepat hingga semua negara di dunia ini mengalami masalah kesehatan yang sama, termasuk pula di Indonesia. Dengan penyebaran yang sangat cepat, dalam waktu kurang dari 3 bulan saja, Covid-19 sudah menyebar hingga 123 negara, dari Asia, Amerika, AS, Eraopa, hingga Afrika Selatan (Sumarmi, 2020). Tanggal 11 Maret 2020, Organisasi kesehatan Dunia (WHO) mengumumkan wabah Covid-19 sebagai pandemi global. Istilah pandemi dimaksudkan sebagai wabah yang berjangkit secara serempak meliputi daerah geografi yang luas. Di Indonesia, kasus Covid-19 pertama kali diumumkan tanggal 2 Maret 2020, dan dalam jangka waktu kurang dari 1 bulan penyakit infeksi ini telah menyebar di berbagai propinsi, dan pada bulan April 2020 penyakit ini sudah 
menjangkiti hampir semua propinsi di Indonesia. Hingga tanggal 19 April 2021 jumlah kasus terkonfirmasi Covid-19 di Indonesia mencapai 1.609.300 dengan jumlah yang meninggal 43.564 orang $(2,7 \%)$ orang, dan jumlah yang sembuh sebesar 1.461.414 orang (90,8\%) sebagaimana data yang direlease oleh Komite Penanganan Covid-19 dan Pemulihan Ekonomi Nasional (KPCPEN, 2021).

Adanya pandemi ini berdampak kepada hampir semua sektor kehidupan masyarakat, tidak hanya kesehatan, sektor ekonomi juga mengalami dampak yang mendalam karena pandemi virus corona. Pembatasan aktivitas masyarakat sosial masyarakat untuk melakukan berbagai aktivitas juga berpengaruh pada aktivitas usaha yang kemudian berimbas pada perekonomian. Aktivitas perekonomian mengalami penurunan disebabkan karena banyaknya industri baik barang maupun jasa yang mengalami penghentian operasinya. Penghentian operasi itu dikarenakan menurunnya daya beli masyarakat dan adanya Pembatasan Sosial Berskala Besar (PSBB) yang menyebabkan ruang gerak dari masyarakat yang banyak terhenti sehingga sangat berpengaruh kepada aktivitas ekonomi, salah satu misalnya adalah sektor transportasi (Mustofa, 2020).

WHO telah mengintruksikan agar menjaga jarak, mendeteksi dan mengisolasi personal yang terkena dampak, meminimmkan interaksi antara manusia dan hewan untuk menghindari penularan virus, mempercepat penelitian dan diagnosa, menyebarluaskan angka dan statistik yang benar kepada masyarakat untuk mencegah terjadinya keresahan di kalangan masyarakat (Meilina, 2020). Beberapa langkah telah dilakukan Pemerintah dalam usaha pencegahan penularan COVID-19 misalnya penggunaan masker, menjaga jarak, selalu mencuci tangan, menggunakan hand sanitizer 
dan juga upaya untuk membatasi pergerakan serta aktivitas masyarakat guna menekan terjadinya penularan virus tersebut.

Gejala COVID-19 yang umum adalah berupa demam, batuk kering, dan rasa lelah. Gejala lainnya yang jarang dan mungkin juga dialami beberapa pasien berupa rasa nyeri dan sakit, hidung tersumbat, sakit kepala, konjungtivitis, sakit tenggorokan, diare, kehilangan indera rasa atau penciuman, ruam pada kulit, atau perubahan warna jari tangan atau kaki. Gejala-gejala yang dialami biasanya bersifat ringan dan muncul secara bertahap. Beberapa orang menjadi terinfeksi tetapi hanya memiliki gejala ringan (WHO, 2020).

Yang menarik, tidak semua pasien COVID-19 menunjukkan gejala, atau hanya menunjukkan gejala ringan, hal ini diduga karena perbedaan kekuatan sistem imun tubuh, dimana pada usia dewasa muda, sistem imun lebih kuat daripada pasien usia lanjut. Penyakit akibat virus memang pada umumnya merupakan 'self-limiting disease' yang mengandalkan kekuatan pertahanan tubuh (Farmasi UGM, 2020). Karena hal tersebut, maka banyak dikampanyekan agar meningkatkan daya tahan tubuh untuk mencegah tertularnya infeksi virus, dan kalaupun tertular, tubuh akan kuat melawannya.

\section{Imunitas}

Imunitas adalah sistem daya tahan tubuh terhadap serangan substansi asing yang terpapar ke tubuh manusia, secara harfiah adalah merupakan pertahanan diri. Jika sistem imun alami tersebut bisa mempertahankan tubuh akibat serangan substansi asing, maka kita tidak akan menderita sakit, dan sebaliknya, jika sistem imun alami tidak bisa mempertahankan dari serangan substansi asing, maka kita akan sakit atau terinfeksi. Ketika virus menginfeksi seseorang, terdapat 3 mekanisme respon imun untuk mengeliminasi infeksi virus, yaitu melalui antibodi, mekanisme sitotoksik dan melalui inferon (Farmasi UGM, 2020). Tingkat imunitas yang dimiliki 
oleh setiap orang tidak sama, beberapa faktor yang dapat mempengaruhi imunitas ialah :

a. Faktor Genetik dan Lingkungan

Fungsi tubuh secara umum bisa dipengaruhi oleh 2 faktor, yaitu informasi genetik yang diturunkan oleh kedua orang tua serta faktor lingkungan. Beberapa aktivitas sistem imun dapat dipengaruhi oleh faktor genetik. Beberapa penelitian menunjukkan faktor lingkungan juga berperan penting bagi perkembangan komponen sistem imun, terutama komponen yang bertanggung jawab kepada pertahan tubuh pada waktu yang panjang.

b. Makanan

Makanan yang dikomsumsi adalah komponen yang utama yang membentuk diri kita. Hal tersebut tidak terkecuali bagi sistem imun tubuh. Sistem imun ini sangat dipengaruhi oleh makanan. Makanan yang kaya lemak dan gula atau seperti pada makanan cepat saji cenderung menyebabkan stress pada sistem imun kita, akibatnya mudah mengalami kerusakan dan menginisiasi penyakit

c. Usia

Usia juga sangat berpengaruh pada kemampuan sistem imun. Seperti selsel lain, pada umumnya sel-sel imun juga berada pada aktivitas puncaknya saat individu sudah dewasa. Setelah itu semakin tua usia sel-sel ini juga akan menurun aktivitasnya, termasuk juga dalam memproduksi protein yang berfungsi melawan infeksi virus, yaitu interferon. Fungsi organ tubuh kita mulai menurun dengan meningkatnya usia.

d. Kondisi Kesehatan

Orang yang memiliki penyakit lebih rentan terhadap serangan infeksi virus. Penyakit kronis atau yang sudah diderita lama seperti kencing manis, jantung, hipertensi, atau kolesterol dan radang hati juga dapat meningkatkan kerentanan terhadap infeksi. Kondisi pikiran yang stress 
juga cenderung dapat meningkatkan kemungkinan individu untuk terkena penyakit infeksi.

e. Konsumsi Obat-obatan

Terdapat beberapa golongan obat-obatan yang diketahui dapat juga menurunkan kemampuan sistem imun untuk mempertahankan diri, salah satunya golongan kortikosteroid serperti kortison, hidrokortison. Penggunaan obat-obat ini apalagi dalam jangka waktu lama sangat mungkin dapat menurunkan kekebalan tubuh kita.

Sistem imun sebenarnya dapat ditingkatkan, dalam keadaan dengan risiko tinggi terhadap terjadinya infeksi seperti saat pandemi Covid-19, diperlukan imunostimulan untuk dapat meningkatkan kemampuan tubuh untuk menangkal infeksi virus. Ada banyak senyawa baik vitamin ataupun herbal dari alam yang sudah tersedia yang diklaim mempunyai efek imunostimulan. Beberapa senyawa yang dapat dipakai untuk meningkatkan kemampuan tubuh dalam menangkal serangan virus diantaranya :

\section{f. Vitamin C}

Studi pada pasien sehat, menunjukkan pemberian vitamin $\mathrm{C}$ dapat memperbaiki beberapa komponen dari parameter imunitas pada manusia. Disamping itu vitamin $\mathrm{C}$ juga menjaga jaringan inang dari kerusakan yang berlebihan akibat peningkatan matinya sel-sel imun. Jadi, vitamin $\mathrm{C}$ diperlukan untuk dapat meningkatkan system kekebalan tubuh dan mempertahankan respon yang cukup memadai terhadap penyebab penyakit dan menghindari kerusakan yang berlebihan pada tubuh.

g. Vitamin D

Vitamin D mendukung aktivasi imunitas antibakteri dan antivirus. 
h. Vitamin E

Vitamin E bersifat sebagai antioksidan yang dapat menetralkan molekul yang tidak stabil yang dapat merusak sel.

i. Herbal Echinacea

Tumbuhan ini secara tradisional digunakan untuk pengobatan dan pencegahan terhadap berbagai penyakit termasuk infeksi saluran pernapasan, sakit gigi, flu, bronchitis, radang tenggorokan, dan infeksi virus. Produk yang mengandung ekstrak Echinacea ini juga terdapat di Indonesia dengan klaim peningkat sistem imun (imunostimulan).

j. Propolis

Propolis adalah produk dari lebah madu yang sering juga disebut sebagai lem lebah. Aktivasi sistem imun oleh propolis diharapkan dapat melindungi seseorang dari infeksi virus atau meningkatkan sistem kekebalan tubuh seseorang sehingga tidak mudah sakit atau menderita keparahan ketika infeksi datang. Disamping itu, Propolis juga mempunyai aktivitas antivirus dengan mencegah replikasi dari virus, termasuk virus tipe korona seperti virus influenza.

k. Empon-Empon

Indonesia kaya akan tumbuhan obat terutama empon-empon yang bisa dimanfaatkan untuk meningkatkan kekebalan tubuh. Beberapa emponempon yang paling umum digunakan dalam pengobatan tradisional di Indonesia dan mudah untuk diperoleh yaitu Jahe, Kunyit, dan Temulawak.

\section{Minuman Pokak Jahe}

Salah satu imbauan yang disampaikan World Health Organization (WHO) ialah perlunya menjaga bahkan meningkatkan daya tahan tubuh (Laily, 2020). Meningkatkan daya tahan tubuh merupakah salah satu cara untuk mencegah serangan virus corona..Ada banyak makanan dan minuman sehat yang dipilih masyarakat untuk meningkatkan daya tahan tubuh. Pokak 
Jahe adalah minuman tradisional yang berasal asal Probolinggo, minuman ini terbuat dari berbagai rempah asli Indonesia, salah satunya, jahe yang mengandung senyawa curcumin dan gingerol, berperan untuk meningkatkan daya tahan tubuh. Selain jahe, minuman pokak juga terbuat dari campuran serai, kayu manis, daun pandan, kapulaga, cengkeh, bunga lawang dan merica, yang kesemuanya mengandung zat antioksidan tinggi. Dengan meminum pokak dapat mengobati masuk angin flu, meredakan batuk, demam, menurunkan tingkat kolesterol, menghilangkan bau badan hingga meningkatkan sistem daya tahan tubuh. Karena itulah minuman herbal ini disebut dapat menangkal virus corona (Fitria, 2020). Untuk membuat minuman Pokak Jahe, diperlukan bahan-bahan sebaai berikut :

\section{Tabel 1}

\section{Bahan Pembuatan Minuman Pokak Jahe}

\begin{tabular}{|c|c|}
\hline Bahan & Banyaknya \\
\hline 1 Serai & 2 batang \\
\hline 2 Kayu mais $( \pm 4 \mathrm{~cm})$ & 1 batang \\
\hline 3 Daun pandan & 2 lembar \\
\hline 4 Kapulaga & 2 buah \\
\hline 5 Cengkeh & 3 buah \\
\hline 6 Bunga lawang/pekak & 1 buah \\
\hline 7 Jahe & $2 \mathrm{~cm}$ \\
\hline 8 Merica butiran & $1 / 2$ sendok makan \\
\hline
\end{tabular}

Sumber : www.wartabromo.com

Sedangkan cara membuatnya adalah sebagi berikut :

a. Pertama, iris tipis serai dan daun pandan. Selanjutnya, campurkan semua bahan dalam panci dan tambahkan air secukupnya.

b. Rebus semua bahan hingga mendidih dan warnanya berubah menjadi kecoklatan. Ketika air mulai berkurang, aroma wanginya mulai tercium, matikan kompor. 
c. Angkat panci berisi rebusan rempah untuk kemudian disaring. Campurkan madu atau sedikit gula jika ingin menambah rasa manis.

Selanjutnya bahan-bahan yang sudah diolah menjadi sirup ini ini dapat diminum dengan cara diseduh terlebih dahulu seperti membuat sirup pada umumnya dan bisa dinikmati hangat atau dingin.

\section{B. METODE}

Kerangka kegiatan pengabdian kepada masyarakat ini dapat digambarkan sebagaimana gambar berikut :

\section{Gambar 1}

Kerangka Kegiatan pengabdian kepada Masyarakat

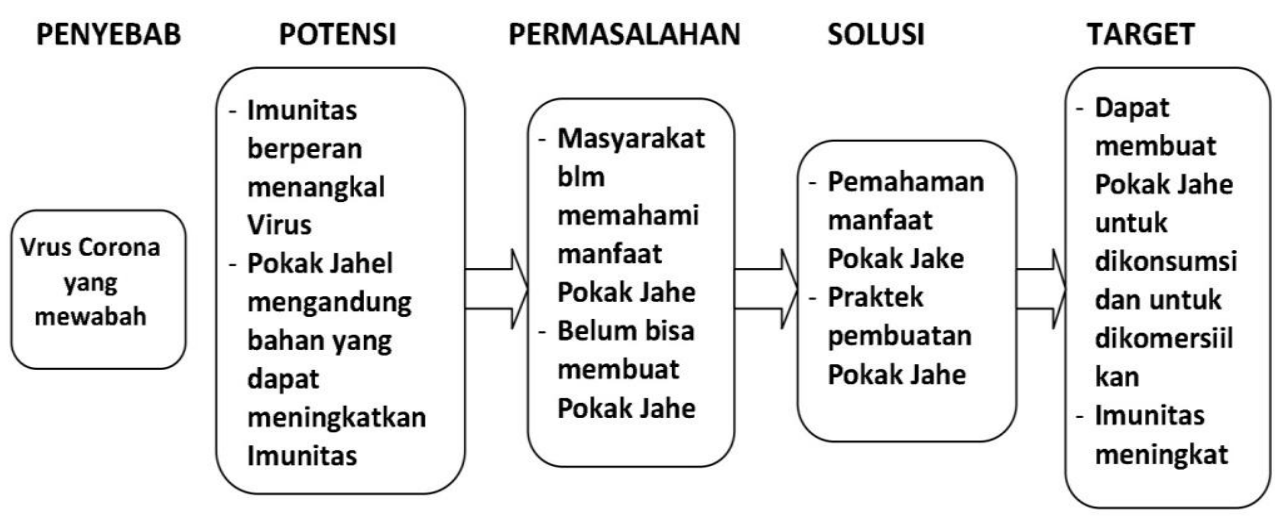

\section{Penyelesaian Masalah}

Untuk memberikan solusi terhadap adanya permasalahan yang ditemui, dilaksanakan beberapa langkah berikut :

a. Sosialisasi Manfaat Minuman Pokak Jahe untuk meningkatkan imunitas dimasa Pandemi Covid-19

b. Sosialisasi cara pembuatan Minuman pokak Jahe dan potensi untuk memproduksi untuk tujuan komersial

c. Pembagian minuman Pokak Jahe kepada warga 


\section{Tahapan pelaksanaan}

Kegiatan pengabdian masyarakat ini dilakukan dengan tahapan berikut :

a. Melakukan pendataan ibu-ibu anggota PKK desa Sumberkedawung, yang dilaksanakan pada tanggal 28 dan 29 Januari 2021.

b. Praktek pembuatan minuman Pokak Jake, dilaksanakan pada tanggal 30 Januari 2021.

c. Membagikan hasil pembuatan minuman Pokak Jake kepada warga dan aparat Desa, dilaksanakan pada tanggal 30 Januari 2021.

\section{HASIL DAN PEMBAHASAN}

Pelaksanaan pengabdian masyarakat ini dilaksanakan pada pada tanggal 28 Januari 2021 hingga 30 Januari 2021, dengan uraian berikut :

a. Pendataan peserta Sosialisasi

Mendata calon peserta untuk diberikan materi tentang manfaat dan cara pembuatan minuman Pokak Jahe

b. Koordinasi rencana penyelesaian masalah Menyiapkan bahan sosialisasi tentang manfaat minumam Pokak Jahe, menyiapkan peralatan dan bahan-bahan yang dibutuhkan untuk membuat minuman Pokak Jahe dan membagikan undangan.

c. Pelaksanaan Kegiatan

Kegiatan Sosialisai dilaksanakan di Balai Desa Sumberkedawung dengan rincian sebagai berikut :

- Pemaparan tentang manfaat minuman Pokak Jahe dalam hubungannya dengan usaha peningkatan imunutas dimasa pandemi Covid-19, dan potensi memproduksi untuk tujuan komersial.

- Praktek pembuatan minuman Pokak Jahe

- Membagikan minuman Pokak Jahe kepada warga 


\section{b. Evaluasi}

Dengan selesainya kegiatan pengabdian tersebut, selanjutnya dilakukan evaluasi trhadap kegiatan yang sudah dilakukan.

\section{Dampak yang diharapkan}

Kegiatan pengabdian ini dilaksanakan dengan harapan adanya manfaat yang dapat diperoleh yaitu :

a. Adanya pemahaman masyarakat tentang manfaat Minuman Pokak Jahe dalam meningkatkan imunitas dimasa Pandemi Covid-19

b. Adanya kemampuan masyarakat dalam membuat minuman pokak Jahe

c. Tumbuhnya inisiatif warga untuk memproduksi Minuman Pokak Jahe dan dipasarkan secara komersial.

\section{Gambar 2.}

Dokumentasi Kegiatan
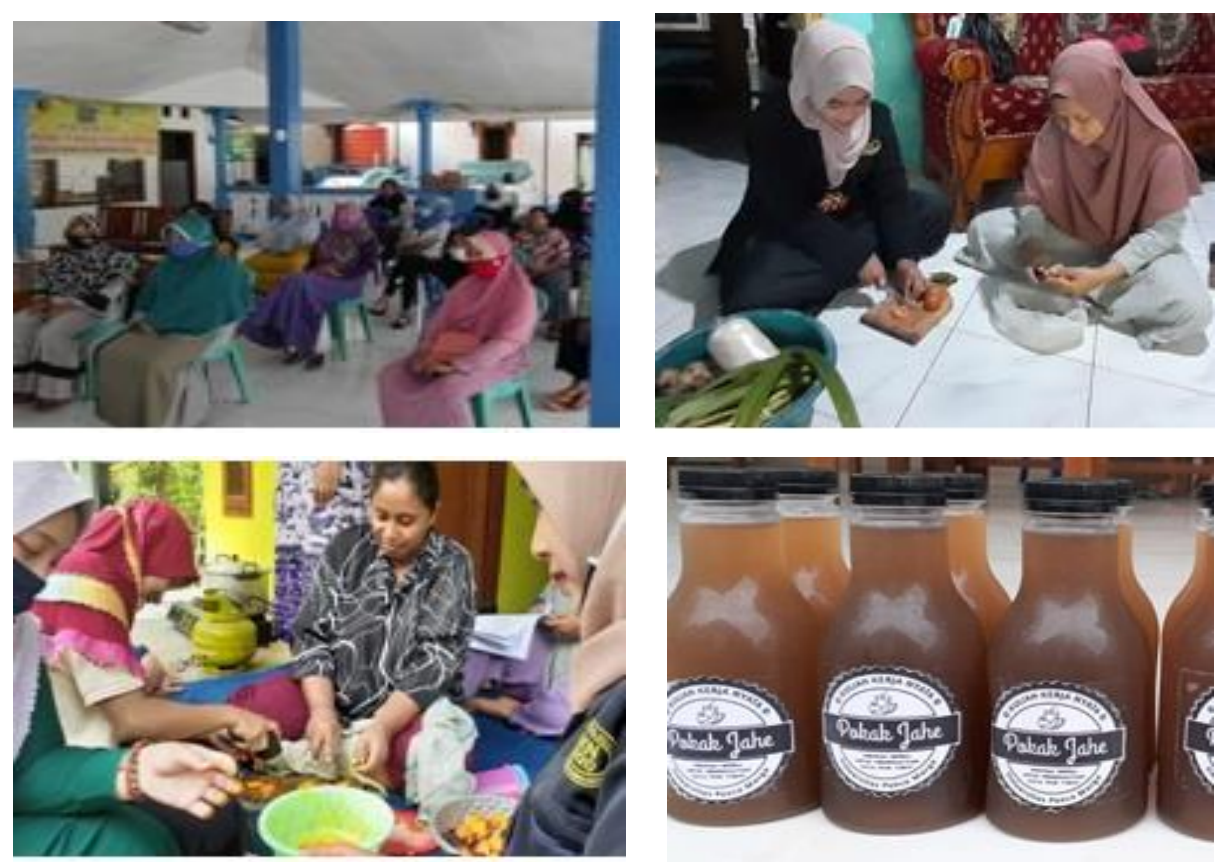

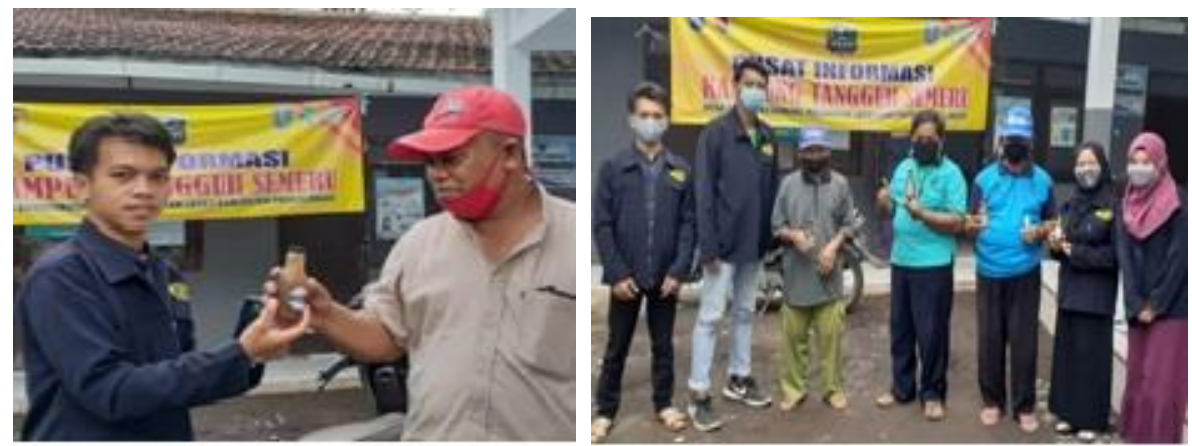

\section{KESIMPULAN}

Wabah covid-19 telah berdampak kepada semua sektor kehidupan masyarakat. Salah satu faktor yang menentukan dalam menghindari dampak dari serangan virus adalah imunitas yang baik. Minuman Pokak Jahe diketahui mengandung bahan herbal yang mempunyai khasiat meningkatkan imunitas tubuh. Kegiatan pengabdian masyarakat ini bermanfaat untuk memberi pemahaman tentang manfaat minuman tradisional Pokak Jake dalam meningkatkan imunitas tubuh, dan memsosialisasikan cara pembuatan minuman Pokak Jake tersebut. Dengan kegiatan ini diharapkan memberi manfaat bagai masyarakat dalam memahami manfaat minuman Pokak Jahe dan mampu membuat minuman tradisional tersbebut, baik untuk dikonsumsi sendiri maupun untuk dikomersiilkan. 


\section{DAFTAR PUSTAKA}

Alami, A. E., Fattah, A., Chait, A. 2020. Medicinal plants used for the prevention purposes during the covid-19 pandemic in Morocco. Journal of analytical sciences and applied biotechnology. Aryanta, I.W. R. 2019. Manfaat Jahe Untuk Kesehatan. Volume 1, Nomor ; 2. E-Jurnal Widya Kesehatan.

Aryanta, I.W. R. 2019. Manfaat Jahe Untuk Kesehatan. Volume 1, Nomor ; 2. E-Jurnal Widya Kesehatan.

Arisandi, B., Mufaizin, M., \& Hasan, M. (2020). Pelatihan Pembuatan Teh Rosella Dalam Meningkatkan Pendapatan Masyarakat di Desa Sorpa Kecamatan Galis Kabupaten Bangkalan. Dharma: Jurnal Pengabdian Masyarakat, 1(1), 28-37.

Aswani, Tuti, 2020 ,

http://www.padk.kemkes.go.id/article/read/2020/04/23/21/hindarilansia-dari-covid-19.html, 23 April 2020

Badan Pusat Statistik (BPS) Kabupaten Probolinggo, 2020, Kecamatan Leces Dalam Angka, CV Azka Putra Pratama

Farmasi UGM, 2020, https://farmasi.ugm.ac.id/id/perlunya-peningkatansistem-imun-pada-pandemi-covid-19/, 16 Agustus 2020

Fitria, Riska, 2020, 5 Fakta Wedang Pokak yang Ampuh Tingkatkan Daya Tahan Tubuh, https:// food.detik.com/info-sehat/d-4954184/5-faktawedang-pokak-yang-ampuh-tingkatkan-daya-tahan-tubuh, 26 Maret 2020.

Haromin, I., Ulum, B., \& Aziz, A. (2020). Pengolahan Jahe Pandan Menjadi Produk Minuman Herbal (Japan) Untuk Meningkatkan Kualitas SDM Ekonomi Kreatif di Desa Kampak Kecamatan Geger. Dharma: Jurnal Pengabdian Masyarakat, 1(1), 49-60.

KPCPEN (Komite Penanganan Covid-19 dan Pemulihan Ekonomi 
Nasional), 2021 https:// covid19.go.id/peta-sebaran-covid19, 20 April 2021

Laily, Rizka Nur, 2020, https://www.merdeka.com/jatim/corona-merebaksirup-pokak-asal-probolinggo-ini-bisa-tingkatkan-kekebalantubuh.html, 17 Maret 2020.

Meilina, Rulia, Revina Dewi, Putri Nadia, 2020, SOSIALISASI PEMANFAATAN TANAMAN OBAT KELUARGA (TOGA) UNTUK MENINGKATKAN IMUN TUBUH DI MASA PANDEMI COVID-19, Jurnal Pengabdian Masyarakat (Kesehatan) Universitas Ubudiyah Indonesia Vol. 2 No. 2 Oktober 2020 Mustofa, Ahmad, Nanik Suhartatik, 2020, MENINGKATKAN IMUNITAS TUBUH DALAM MENGHADAPI PANDEMI COVID-19 DI KARANGTARUNA KEDUNGGUPIT, SIDOHARJO, WONOGIRI, JAWA TENGAH, SELAPARANG. Jurnal Pengabdian Masyarakat Berkemajuan, Volume 4, Nomor 1, November 2020

Sumarmi, Sri, 2020, Kerja Harmoni Zat Gizi dalam Meningkatkan Imunitas Tubuh Terhadap Covid-19: Mini Review, IAGIKMI \& Universitas Airlangga, DOI: 10.2473/amnt.v4i3.2020. 250-256

Warta Bromo, 2020, Tingkatkan Daya Tahan Tubuh dengan Wedang Pokak, Ini Resepnya! https://www.wartabromo.com/2020/03/28/tingkatkandaya-tahan-tubuh-dengan-wedang-pokak-ini-resepnya/

WHO, 2020, Novel Corona Virus : Q and A for public, https://www.who.int/ indonesia/news/ novelcoronavirus/qa-for-public

Widayanto, Mutinda Teguh, 2019, Edukasi Kesehatan bagi Ibu dan Calon Ibu Sebagai Upaya Pencegahan Masalah Stunting di Desa Jatiadi Kecamatan Gending, Kabupaten Probolinggo, Jurnal Abdi Panca Marga, Vol. 1, No. 1, : 10-14 